\section{PRÁCTICAS POLÍTICAS,} COALICIONES GUBERNAMENTALES Y CAMBIO INSTITUCIONAL:

\section{LA FRAGUA DE LA RIVALIDAD}

ENTRE PARTIDOS EN EL CICLO

DE REFORMAS CONSTITUCIONALES

PROVINCIALES, MENDOZA, 1889-1900

POLITICAL PRACTICES, GOVERNMENT

COALITIONS AND INSTITUTIONAL CHANGE:

THE FORGE OF POLITICAL PARTIES RIVALRIES IN

THE CYCLE OF PROVINCIAL CONSTITUTIONALS

REFORMS, MENDOZA, 1889-1900

BEATRIZ BRAGONI •

Beatriz Bragoni es Investigadora Independiente del CONICET, con sede en el Instituto de Ciencias Humanas, Sociales y Ambientales, Centro Científico Tecnólógico/CONICET, Universidad Nacional de

\section{Resumen}

Este artículo analiza la dinámica política de la provincia de Mendoza entre 1889 y 1900 con el interés de abonar la agenda de investigación sobre la formación y funcionamiento de los regímenes liberales decimonónicos. En particular, postula la institucionalización de agrupaciones rivales al partido oficial, y subraya su incidencia en la transformación del régimen político e institucional. La vinculación entre las prácticas políticas derivadas de la emergencia de partidos o agrupaciones políticas en litigio con el poder gubernamental, y sus efectos correlativos en los cambios políticos e institucionales derivados de tales innovaciones, resultan indicativos para explorar algunas convenciones de la historiografía política reciente que aconseja complejizar el análisis de los regímenes liberales.
Mendoza (Argentina).

Av. Ruiz Leal s/n, Parque Gral. San Martín, Mendoza. E-mail: bbragoni@lanet.com.ar

\section{Abstract}

This article analyzes the political dynamics of the province of Mendoza between 1889 and 1900 with the interest of expanding the research agenda on the formation and functioning of nineteenth - century liberal regimes. In particular, it postulates the institutionalization of groups rivaling the official party, and emphasizes their impact on the transformation of the political and institutional system. The link between political practices stemming from the emergence of political parties or groups in dispute with government power, and its correlative effects on the political and institutional changes derived from such innovations, are indicative to explore some conventions of recent political historiography that advises to deepen the analysis of liberal regimes. 